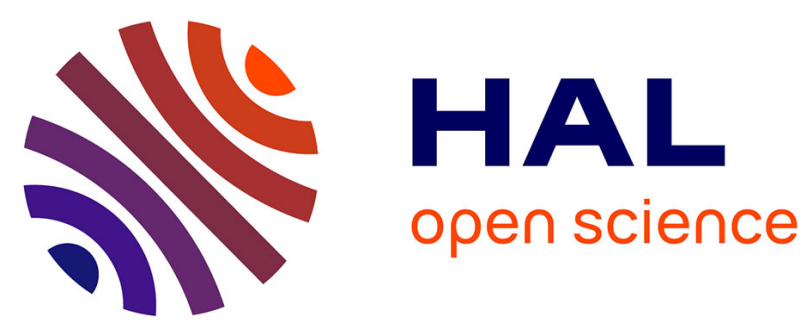

\title{
Sexual Health Problems and Discussion in Colorectal Cancer Patients Two Years After Diagnosis: A National Cross-Sectional Study.
}

Thierry Almont, Anne-Deborah Bouhnik, Ali Ben Charif, Marc-Karim

Bendiane, Corinne Couteau, Cécile Manceau, Julien Mancini, Eric Huyghe

\section{To cite this version:}

Thierry Almont, Anne-Deborah Bouhnik, Ali Ben Charif, Marc-Karim Bendiane, Corinne Couteau, et al.. Sexual Health Problems and Discussion in Colorectal Cancer Patients Two Years After Diagnosis: A National Cross-Sectional Study.. Journal of Sexual Medicine, 2019, 16 (1), pp.96-110. 10.1016/j.jsxm.2018.11.008 . inserm-02556102

\section{HAL Id: inserm-02556102 https://www.hal.inserm.fr/inserm-02556102}

Submitted on 21 Oct 2021

HAL is a multi-disciplinary open access archive for the deposit and dissemination of scientific research documents, whether they are published or not. The documents may come from teaching and research institutions in France or abroad, or from public or private research centers.
L'archive ouverte pluridisciplinaire HAL, est destinée au dépôt et à la diffusion de documents scientifiques de niveau recherche, publiés ou non, émanant des établissements d'enseignement et de recherche français ou étrangers, des laboratoires publics ou privés.

\section{(ㅇ)(1) $\$$}

Distributed under a Creative Commons Attribution - NonCommerciall 4.0 International 
1 Sexual health problems and discussion in colorectal cancer patients 2 years after 2 diagnosis: A national cross-sectional study

\section{Authors (Firstname Name)}

5 Thierry Almont, MSc, PhD ${ }^{\mathrm{A}, \mathrm{B}}$, Anne-Déborah Bouhnik, MSc, PhD ${ }^{\mathrm{C}, *}$, Ali Ben Charif, MSc, $6 \mathrm{PhD}^{\mathrm{D}, \mathrm{E}}$, Marc-Karim Bendiane, MSc, $\mathrm{PhD}^{\mathrm{C}}$, Corinne Couteau, $\mathrm{MD}^{\mathrm{F}}$, Cécile Manceau, $\mathrm{MD}^{\mathrm{B}}$, 7 Julien Mancini, MD, MPH, $\mathrm{PhD}^{\mathrm{C}}$, Éric Huyghe, MD, MSc, $\mathrm{PhD}^{\mathrm{A}, \mathrm{B}, \mathrm{G}}$

\section{Institutional addresses}

${ }^{\text {A }}$ EA 3694 Human Fertility Research Group, Université Paul Sabatier Toulouse 3 - CHU

11 Toulouse Paule de Viguier, Reproductive Medicine Department, 330 avenue de Grande12 Bretagne, TSA 70034, 31059 Toulouse cedex 9, France.

$13{ }^{\mathrm{B}}$ French Education and Research Group in Andrology, Urology and Sexology (GEFRAUS),

${ }^{\mathrm{C}}$ Sciences Economiques \& Sociales de la Santé \& Traitement de l'Information Médicale, Aix Marseille University, INSERM, IRD, SESSTIM, 27 Boulevard Jean Moulin, 13385, Marseille cedex 5, France

D Health and Social Services Systems, Knowledge Translation and Implementation component of the Quebec SPOR-SUPPORT Unit, Université Laval, Quebec, QC, Canada

E Tier 1 Canada Research Chair in Shared Decision Making and Knowledge Translation,

22 Université Laval, Quebec, QC, Canada

23 F CHU Toulouse (IUCT-Rangueil-Larrey), Digestive Cancer Department, 1 Avenue du 24 Professeur Jean Poulhès, 31059 Toulouse cedex 9, France

$25{ }^{\mathrm{G}}$ Francophone Association for Supportive Care (AFSOS), 33130 Bègles, France 
* Corresponding author

Anne-Déborah Bouhnick, MSc, PhD

29 Sciences Economiques \& Sociales de la Santé \& Traitement de l'Information Médicale, Aix

30 Marseille University, INSERM, IRD, SESSTIM, 27 Boulevard Jean Moulin, 13385, Marseille

31 cedex 5, France

32 Phone: +33491223501 | Email: anne-deborah.bouhnik@inserm.fr

\section{Email addresses for all authors}

TA, almont.t@theral.fr

36 ADB, anne-deborah.bouhnik@inserm.fr

37 ABC, ali.ben-charif.1@ulaval.ca

38 MKB, marc-karim.bendiane@inserm.fr

39 CC, couteau.c@ chu-toulouse.fr

40 CM, cecile.manceau2@gmail.com

41 JM, julien.mancini@univ-amu.fr

42 EH, eric.huyghe@yahoo.fr

43

44 Short title

45 Sexual health in colorectal cancer patients

\section{$47 \quad$ Keywords}

48 Oncosexology, Sexual Quality of life, Discussion about sexuality, Colorectal Cancer,

49 Supportive care, VICAN survey 


\begin{abstract}
Background: Colorectal cancer (CRC) is accompanied by specific treatment-related physical (ostomy, incontinence) and psychosexual (body image, depression) consequences on sexual health.
\end{abstract}

Aim: An assessment of sexual health of CRC patients 2 years after diagnosis.

Methods: We selected all CRC patients of a French nationwide longitudinal study. Data sources included patient questionnaires, medical questionnaires and medico-administrative databases.

Outcomes: We evaluated sexual health using the Relationship and Sexuality Scale and assessed self-reported rates of discussion about sexuality with health care providers.

Results: Across the 487 patients, 258 were men and 229 were women, with $77 \%$ diagnosed with colon cancer and $23 \%$ with rectal cancer. Overall, $54 \%$ of patients reported a decrease in sexual desire, $61 \%$ a decrease in frequency of intercourse, and $48 \%$ a decrease in the possibility to reach an orgasm. Patients still experiencing fecal incontinence 2 years after diagnosis have all sexual desire, intercourse, orgasm and satisfaction RSS items decreased. Rectal cancer patients had significantly more frequent desire and orgasm troubles than colon cancer patients ( $p=.003 ; p=.014$, respectively). Regarding the discussion about sexuality, only $20 \%$ of men and $11 \%$ of women; $11 \%$ of colon cancer and $33 \%$ of rectal cancer patient recalled having discussed sexuality with the medical team. Factors independently increasing the chance to have discussed sexuality with the medical team were being younger $(\mathrm{OR}=2.77$ $[1.31 ; 5.84], \mathrm{p}=.007)$, having an ostomy $(\mathrm{OR}=2.93[1.27 ; 6.73], \mathrm{p}=.011)$ and radiotherapy $(\mathrm{OR}=2.78$ [1.23; 6.27], $\mathrm{p}=.014)$.

Clinical Implications: These results highlight the need for developing interventions to improve information delivery at cancer announcement and for managing sexual troubles during survivorship in CRC patients, particularly those experiencing fecal incontinence. 
Strengths \& Limitations: Strengths are the sample size, the national representativeness using the data of a large-scale nation-wide survey, the possibility to compare colon and rectal cancers. Limits are the assessment of sexuality 2 years after diagnosis, using only selfreported measures.

Conclusion: This study highlights the lack of discussion about sexuality with the oncology team and the need for specific sexual rehabilitation interventions, especially for patients with rectal cancer and fecal incontinence. Developing these aspects may help CRC patients improve their sexual prognosis. 


\section{INTRODUCTION}

Colorectal cancer (CRC) is the third most frequent cancer (2nd in women), with 43068 new cases diagnosed in France in 2015 [1]. With a 5-year survival estimated at 56\%, the CRC is the digestive cancer with the best survival prognosis [2], making quality of life an area that deserves greater attention, including sexuality. Cancer survivors are a population at risk of treatment-related sexual impairments $[3,4]$. Between $40 \%$ and $100 \%$ of patients subsequently experience sexual disorders [4,5], particularly those with pelvic or breast tumors [6,7]. Overall, in CRC patients, up to $88 \%$ of men and a half of women experience sexual disorders after treatment [8], with high rates in rectal cancer patients (up to $69 \%$ of men an $62 \%$ of women) [9]. CRC come with specific treatment-related effects on sexual health, including physical aspects like ostomy, rectal discharge, gas, incontinence, but also psychosexual consequences like body image, depression and anxiety [10,11]. Personal distress is higher in cancer patients with low personal control who perceive their partner as having unsupportive behavior [12]. In couples coping with CRC, partners' supportiveness is reported to possibly maintain relationship satisfaction [13]. Unfortunately, literature concerning treatment-related sexual disorders in CRC has several limits. Systematic reviews about sexual functioning in CRC patients after treatment highlighted wide ranges in the prevalence of sexual dysfunctions possibly related to methodological limits (i.e. small sample size, retrospective design, and empirical evaluation) $[14,15]$. Another weakness is that most of the literature focuses on excitement (erectile function in men and lubrication in women) [14,16-19], with a few data concerning the other domains of sexual function, like sexual desire and orgasm difficulties $[8,9,15]$. Finally, there is a lack of detailed evaluation regarding women, comparing colon and rectal cancer, and analyzing the impact of ostomy and fecal incontinence.

Recently, the French national VICAN survey assessed several aspects of cancer patients' quality of life 2 years after diagnosis, including sexual health problems [20-22]. However, 
since the VICAN survey focused on the impact of cancer on employment, previous reports did not provide detailed information on patients' sexual life.

Therefore, we aimed at focusing thoroughly on VICAN CRC patients' sexual health and disorders 2 years after diagnosis. A second objective was to assess discussion about sexuality with Health Care Providers (HCPs).

\section{METHODS}

\section{Study design}

The VICAN survey is a nationwide longitudinal study that currently includes two crosssectional surveys (at 2 and 5 years after diagnosis) with the same objectives and various topics for cancer survivors [22,23]. For more details, the methodology of the "Vie après cancer" (VICAN) study was published elsewhere [22].

\section{Setting}

The VICAN 2-year survey was carried out in France between March and December 2012. It included cancer patients initially diagnosed or managed in public centers (academic or nonacademic hospital), comprehensive cancer centers, and/or private centers [22].

\section{Participants}

The VICAN study targeted men and women aged 20-84 at the time of the survey, diagnosed between January and June 2010 and registered in the Long Duration Disease File of the National Health Insurance File of one of the three main French Health Insurance Schemes which cover $>90 \%$ of the population. It was restricted to 12 cancer sites with good, intermediate or poor prognosis, accounting for $88 \%$ of cancer incidence in France. Eligibility 
was French-speaking patients diagnosed with first malignant cancer and living in France for at least 2 years [22]. For the purposes of the current study, we restricted to CRC patients.

\section{Data collection}

Three sources of data were used in the VICAN survey: patient questionnaires, medical surveys completed by physicians who initiated cancer treatment and medico-administrative databases. Patients were identified with the medico-administrative databases and received a letter of invitation to participate in computer-assisted telephone interviews.

Patient questionnaire included socio-demographic characteristics, comorbidities and the sexual health validated psychometric scale.

\section{$\underline{\text { Sexual health assessment }}$}

Sexual health from the onset of cancer was evaluated using 6 items from the «Relationship and Sexuality Scale (RSS) », validated by Berglund et al. [24]. The RSS has been developed for women, but the items in this questionnaire are not gender-dependent and have been used previously for assessing relationship and sexuality in both genders [25-27].

The first 3 items used are from the "sexual function" dimension in the RSS and were used to measure patients' perception of deterioration of the following factors since cancer diagnosis: sexual desire (range 0 to 3), orgasm (range 0 to 4) and frequency of sexual intercourse (range 0 to 4 ). For each of these three items, higher scores were indicative of poorer perceived sexual conditions.

The last 3 items used are from the "sexual frequency" dimension in the RSS, assessing satisfaction with the frequency of hugs and kisses, satisfaction with the frequency of 
intercourse and frequency (no.) of intercourse during the last 2 weeks. Each item was scored from 0 to 4 , higher scores indicating higher frequency.

All the 6 items, out of the 9 proposed by Berglund et al. [24], were used separately. In that respect, unless each item in Berglund's scale is validated, the scores on the individual items have face validity only.

\section{$\underline{\text { Cancer site }}$}

The International Classification of Diseases (ICD-10) from the medico-administrative databases was used to classify patients with "Colon cancer" (Cecum, C18 + Rectosigmoid junction, C19) and "Rectal cancer" (Rectum, C20).

\section{$\underline{\text { Medical characteristics }}$}

Medical and medico-administrative databases were used to collect data on patient treatments including surgery, chemotherapy regimen, radiotherapy and endocrine therapy. Missing data were completed with patients and physician-reported information.

\section{Ostomy}

Medical and medico-administrative databases were used to collect information about the existence of permanent or temporary ostomy. Missing data were supplemented with information from patients' and physicians' questionnaires.

\section{$\underline{\text { Fecal incontinence }}$}

We used patient-reported information about their experiencing of fecal incontinence through ostomy or the anus, when applicable. 


\section{Discussion about sexuality with HCPs}

Patient questionnaires included an item on sexuality-related discussions with HCPs: "Since cancer diagnosis, have you talked about your sexual health with health care staff?" Four responses were proposed: "yes, at the initiative of the staff," "yes, on my own initiative," "no, I did not wish to," and "no, nobody proposed it to me." This item referred to any visit during the past 2 years since diagnosis and was inspired by similar measurements developed by Gilbert et al. [28]; their three simple items were combined into a one-item measurement.

\section{Study size}

The final VICAN study sample included 4349 participants (global response rate of $43.7 \%$ ), including 487 CRC patients [22].

\section{Statistical analysis}

A weighting procedure was first performed to make the CRC sample representative of the target population according to age and insurance plan disease. The weights were calculated in order to make the sample structure identical, in terms of age and health insurance scheme, to that observed in the sampling frame. For each stratum of the sample, the weight of the survey was calculated as the inverse of the survey rate (total number selected individuals / size of the stratum in the frame).

We analyzed data using Mann-Whitney and t-tests to compare age, and RSS scores by gender, cancer site, ostomy and fecal incontinence. Chi-square and Fisher exact tests were used to compare discussion rates and social, medical and RSS categories by gender, cancer site, ostomy and fecal incontinence. Univariate linear regressions were performed to describe variables associated with each RSS sexual item. Univariate logistic regressions were performed to describe factors associated with the discussion about sexuality. All variables 
whose critical probability (p) was $<.20$ in univariate analyses were eligible for the multivariate models. When eligibility was were not applicable, potential confusing variables were systematically entered in the regression models (age, gender, partnership, having children, education, having a job, household income, cancer treatments and having diabetes). Statistical analyses were performed using Stata version 14 (Stata Corp., College Station, TX, USA) and weighted to ensure representativeness at a national level. Statistical significance was considered to be $\mathrm{p}<.05$. Findings are reported according to the STROBE statement.

\section{RESULTS}

\section{Participants}

The sample included 487 patients with CRC, who responded to a phone survey, 2 years after their diagnosis. (Figure 1)

\section{Characteristics of participants}

Descriptive results of participants are outlined in Table 1. Most CRC patients were men $(\mathrm{n}=258,53 \%)$, older and more likely to live in couple or have diabetes than women. There was no difference between men and women in occupation, education and monthly income.

The studied sample was composed of 374 colon (77\%) and 113 rectal (23\%) cancers. Women had a higher proportion of colon cancer than men $(\mathrm{p}=.002)$ and underwent less frequently radiotherapy $(\mathrm{p}<.001)$. (Table 1$)$

\section{Sexual disorders}


Overall, 54\% (235/435) of patients reported a decrease in sexual desire, 61\% (246/402) a decrease in frequency of intercourse, and 48\% (191/395) a decrease in the possibility to reach an orgasm. However, 89\% (339/382) of patients were satisfied with the frequency of hugging and kissing, and 77\% (301/389) with the frequency of intercourse. Of the respondents, $60 \%$ (235/435) declared they had at least one sexual intercourse during the last two weeks. Men and women were comparable for all assessed sexual issues.

\section{Decrease in sexual desire}

Factors positively associated with a decrease in sexual desire in multivariate analyses were rectal cancer and fecal incontinence, while patients with higher monthly income were less likely to report a decrease in their sexual desire. (Table 2)

\section{Decrease in the frequency of intercourse}

Employment status at diagnosis, chemotherapy, surgery and fecal incontinence were factors independently associated with a decrease in the frequency of intercourse, while patients with higher monthly income were also less likely to report a decrease in the frequency of sexual intercourse. (Table 3)

\section{Difficulty to reach orgasm}

Age, employment status at diagnosis, cancer site and fecal incontinence were factors independently associated with difficulty to reach orgasm, while patients with a higher education or diabetes were less likely to report such a difficulty. (Table 4)

\section{Satisfaction with the frequency of hugging and kissing}


Factors negatively associated with satisfaction with the frequency of hugging and kissing in multivariate analyses were age, having dependent children, chemotherapy and fecal incontinence. (Table 5)

\section{Satisfaction with the frequency of intercourse}

Age, employment status at diagnosis and fecal incontinence were factors negatively associated with satisfaction with the frequency of intercourse, while patients with higher income were more likely to be satisfied. (Table 6)

\section{Frequency (no.) of intercourse during the last two weeks}

Age, chemotherapy and fecal incontinence were negatively associated with the frequency (no.) of intercourse during the last two weeks in multivariate analyses, while patients with ostomy were more likely to report a higher frequency. (Table 7)

\section{Discussion about sexuality}

Of the 466 respondents, only $16 \%$ of patients recalled having discussed sexuality with the medical team. In the univariate analysis women and colon cancers had received an information significantly less frequently than men ( $11 \%$ of women vs. $20 \%$ of men: $p=.025)$ and rectal cancers (11\% of colon cancers vs. $33 \%$ of rectal cancers: p .004), respectively. In the weighted multivariate analysis, factors remaining independently associated to discussion about sexuality are younger age $(\mathrm{OR}=2.76[1.31 ; 5.84], \mathrm{p}=.007)$, having ostomy $(\mathrm{OR}=2.93$ [1.27; 6.73], $\mathrm{p}=.011)$ and radiotherapy $(\mathrm{OR}=2.78$ [1.23; 6.27], $\mathrm{p}=.014)$. (Table 8). 


\section{DISCUSSION}

To our knowledge, our study is the first to assess both sexual health problems and discussion about it in a large national representative sample of CRC patients. We found frequent sexual problems, but a lack of information delivery concerning these problems. However, physicians might often assume that this finding is almost exclusively true for patients with rectal cancer. Indeed, surgery of rectal cancer may damage vasculo-nervous bundles, what may result in a neurogenic erectile dysfunction in males and may disrupt sexual response in women [16]. Surgery and/or radiotherapy of colon cancer should not result in such organic disturbances.

Our results confirm that rectal cancer patients are a population facing a high risk of sexual troubles 2 years after cancer diagnosis, since, in multivariate analyses, they had a higher alteration of sexual desire in $68 \%$ and more difficulty reaching an orgasm in $71 \%$, than patients with colon cancer. Additionally, a higher proportion of rectal cancer patients were more dissatisfied with the frequency of intercourse and less likely to have intercourse during the last two weeks, in univariate analyses only. However, colon cancer should not be overlooked, as a significant proportion of patients treated for a colon cancer have a deterioration of their sexual life following cancer treatment. Whereas Frick et al. only observed erectile dysfunction in $17.9 \%$ of male colon cancer survivors and sexual changes in $36.8 \%$ of female colon cancer survivors [19], we observed more recurrent issues in this population with an alteration of libido in $50 \%$, a difficulty to reach orgasm in $42 \%$, and $37 \%$ of patients with colon cancer having no intercourse during the last two weeks.

Therefore, we may argue that whatever the location of CRC, the issue of sexuality should be addressed to the patients.

Comparing genders, CRC women have similar RSS scores as men for any of the studied items. Rates for decrease in desire, frequency of intercourse and orgasm RSS items rank high 
both in men and women (at least 1 patient out of 2). In another study including 78 CRC patients undergoing chemotherapy [29], we also found a high frequency of disorders in women ( $87 \%$ had at least desire, excitement and pain issues at the same time). Interestingly, in this previous study, we found that sexual rehabilitation interventions in digestive cancer were less effective in women than in men, even though women were willing to use a sexual health service as frequently as men (45\% vs. 43\%, respectively; $\mathrm{p}=.820)$ [29]. Physicians should not conclude wrongly that women with CRC would not deserve sexual rehabilitation. Correspondingly, a recent Internet-based survey involving 1129 lower gastrointestinal cancer survivors, showed that sexual changes were reported by $36.8 \%, 62 \%$ and $45.2 \%$ of female colon, rectal and anal cancer survivors $(\mathrm{p}<.01)$, respectively [19]. It is urgent to develop specific interventions for women as effective as those available for men.

Regarding their effects, our results clearly show that ostomy or fecal incontinence are a group with a significant impact on sexuality. While patients with fecal incontinence during the past seven days have a deterioration of all the RSS sexual life items (desire, number and frequency of intercourse, capacity to reach orgasm, satisfaction with hugging and kissing and satisfaction with frequency of intercourse) after multivariate analyses, patients who have been treated with an ostomy have similar RSS item issues than patients without. This result can be explained by the fact that only 34 patients (7\%) still have an ostomy 2 years after diagnosis. The psychological impact of ostomy, notably on self-esteem and body image have ever been highlighted [30,31]. However, for long, digestive surgeons have worked to develop surgical procedures that do not require the wearing of a definitive stoma [32-34]. For this reason, rectal cancer surgery with anterior resection and colo-anal anastomosis is presented as better preserving sexual quality of life than abdominoperineal amputation, imposing the wearing of a definitive stoma. The reality is more complex. Our results show that, even if both ostomy 
and fecal incontinence impact sexual desire and frequency of intercourse, in univariate analyses, the troubles are more critical for fecal incontinence, concerning all 6 items measured in multivariate analyses. Another element of understanding is that patients with ostomy discussed more frequently sexuality with the medical team, contrary to fecal incontinence which was not associated with the discussion about sexuality.

Concerning communication about sexuality, a lack of information delivery about sexual impacts of CRC and its treatment has been observed by several studies [21,35-39]. Unlike those studies, we observed no statistically significant difference between men and women in information delivery after multiple adjustments. However, in our CRC population, only $16 \%$ of patients ( $11 \%$ women and $20 \%$ men) reported having discussed sexuality with the medical team throughout their care management. This result highlights the need for improving information delivery and counseling in CRC patients. In that respect, Reese et al. performed a pilot study of a telephone-based intervention teaching CRC patients and their partners cognitive and behavioral skills for coping with sexual changes. The authors concluded that such an intervention is feasible and holds promise for improving sexual and intimacy outcomes in CRC patients and their partners [40].

The deficient proportion of informed patients may be explained by the fact that $77 \%$ of our sample was composed of colon cancer. The non-pelvic location could have led oncologists to consider that the risk of sexual damage was not an important issue. However, even the sexual function is less likely to be impacted in colon cancers, this cancer site is known to come with specific physical and psychosexual issues [11]. Low rates of informed patients could also be explained by all the barriers to communication about sexuality reported in literature, like lack of time, embarrassment, discomfort, lack of knowledge, lack of confidence, difficulties to refer patients to a specialist, uncertainty regarding responsibility for active counselling, sex as 
irrelevant or inappropriate for some patients, or structural constraints in the clinical setting $[36,41-43]$.

We also observed that patients aged under 55 (sample mean age) received more frequently information about sexuality than older ones. This result highlight that stereotypical beliefs regarding the sexuality of seniors remain a steady issue $[44,45]$. Therefore, it would be valuable to convince health care professionals that sexuality remains a fundamental component of quality of life, regardless of the age of patients [46-49].

Since main barriers to the discussion are well documented, healthcare providers should now be encouraged to seek training in sexual health, particularly in oncosexology as it relates to cancer and its treatments. A previous survey including 165 healthcare professionals providing sexology care to cancer patients showed that $75.8 \%$ of respondents would like specific training in oncosexology, even those who were already degreed in sexology [50]. This illustrates the fact that oncosexology is an emerging specific field of sexology necessitating specific training programs [51].

\section{Study strengths and limitations}

The strengths of our study were the sample size, its national representativeness using the data of a large-scale nation-wide survey, and the possibility to compare colon and rectal cancers based on detailed and reliable data from the combination of patient-reported outcomes, medical records and medico-administrative databases.

However, the cross-sectional analysis performed was a limitation without any assessment of sexuality before cancer diagnosis for the 3 items evaluating 3 "sexual frequency".

Another limit concerns missing data treated by using standard complete data methods. Nevertheless, missing data regarding information were relatively rare $(4 \%)$ and were limited from $11 \%$ to $21 \%$ for the RSS, depending on the items. 
Finally, the VICAN survey shares the general limitations of any approach using self-reported questionnaires, like memory or social desirability bias for instance. 


\section{CONCLUSION}

This study is an original approach to sexuality assessment in CRC patients, comparing colon versus rectal cancer, as well as assessing the impact of ostomy and fecal incontinence. It revealed that more than half of patients experience an impact of disease and treatments on their sexual life two years after diagnosis. These results highlight the need for specific and effective sexual rehabilitation interventions, especially for patients with fecal incontinence and rectal cancer. Such an implementation may help them to improve their sexual prognosis. Another interest of this study is to sensitize health care professionals about the lack of communication about sexuality with the medical team particularly seniors, those without ostomy, and those not having radiotherapy, who were populations less likely to discuss sexuality.

\section{LIST OF ABBREVIATIONS}

CRC, Colorectal Cancer

HCPs, Health Care Providers

OR, Odds Ratio

RSS, Relationship and Sexuality Scale

VICAN, Vie après Cancer (life after cancer)

\section{DECLARATIONS}

\section{Ethics approval}

The VICAN study complied with the Helsinki declaration and was approved by three French national ethics commissions: The Advisory Committee for Data Processing in Health Research (CCTIRS, study No. 11-143), the French Institute of Public Health (ISP, study No. C11-63), and the French Commission on Individual Data Protection and Public Liberties (CNIL, study No. 911290) [22]. 


\section{Competing interests}

The authors declare that they have no competing interests.

\section{Funding}

The VICAN study was funded by the French National Institute of Cancer (Institut National du Cancer, INCa) “Contrat de recherche et développement no 05-2011”. TA was supported by the French National League Against Cancer (PhD grant $n^{\circ}$ TDTJ12441- 2013e2016). Only the authors have responsibility for the information provided in this article.

\section{Authors' contributions}

Julien Mancini was involved in VICAN survey conception and design, manuscript drafting, interpretation of data and critical discussion.

Eric Huyghe was involved in CRC study design, manuscript drafting, interpretation of data and critical discussion.

Anne-Déborah Bouhnik and Marc-Karim Bendiane were involved in data collection, weighting procedures, manuscript drafting, interpretation of data and critical discussion.

Thierry Almont was involved in statistical analyses, interpretation of data, tables and figures design, manuscript drafting and critical discussion.

Ali Ben-Charif, Corinne Couteau and Cécile Manceau were involved in manuscript drafting, interpretation of data and critical discussion. 


\section{Acknowledgements}

We gratefully acknowledge the VICAN Group for allowing us to analyze their data. 


\section{REFERENCES}

1. French National Institute for Cancer (2016) Les cancers en France en 2015. http://www.ecancer.fr/Expertises-et-publications/Catalogue-des-publications/Les-cancers-en-FranceEdition-

2. Mazeau-Woynar V, Cerf N (2010) Survie attendue des patients atteints de cancers en France: état des lieux. Paris: Institut national du cancer. https://doi.org/10.1111/j.13497006.2008.00920.x/full

3. Schover LR, van der Kaaij M, van Dorst E, Creutzberg C, Huyghe E, Kiserud CE (2014) Sexual dysfunction and infertility as late effects of cancer treatment. European Journal of Cancer Supplements 12 (1):41-53. https://doi.org/10.1016/j.ejcsup.2014.03.004

4. Sadovsky R, Basson R, Krychman M, Morales AM, Schover L, Wang R, Incrocci L (2010) Cancer and sexual problems. J Sex Med 7 (1 Pt 2):349-373. https://doi.org/10.1111/j.17436109.2009.01620.x

5. National Health Institute (2006) The prevalence and types of sexual dysfunction in people with cancer. www.cancer.gov. June 13, 2012

6. Bober SL, Varela VS (2012) Sexuality in adult cancer survivors: challenges and intervention. J Clin Oncol 30 (30):3712-3719. https://doi.org/10.1200/JCO.2012.41.7915

7. Brotto LA, Yule M, Breckon E (2010) Psychological interventions for the sexual sequelae of cancer: a review of the literature. J Cancer Surviv 4 (4):346-360.

https://doi.org/10.1007/s11764-010-0132-z

8. Traa MJ, De Vries J, Roukema JA, Den Oudsten BL (2012) Sexual (dys)function and the quality of sexual life in patients with colorectal cancer: a systematic review. Ann Oncol 23 (1):19-27. https://doi.org/10.1093/annonc/mdr133 
9. Hendren SK, O'Connor BI, Liu M, Asano T, Cohen Z, Swallow CJ, Macrae HM, Gryfe R, McLeod RS (2005) Prevalence of male and female sexual dysfunction is high following surgery for rectal cancer. Ann Surg 242 (2):212-223

10. Krouse R, Grant M, Ferrell B, Dean G, Nelson R, Chu D (2007) Quality of life outcomes in 599 cancer and non-cancer patients with colostomies. The Journal of surgical research 138 (1):79-87. https://doi.org/10.1016/j.jss.2006.04.033

11. Mols F, Lemmens V, Bosscha K, van den Broek W, Thong MS (2014) Living with the physical and mental consequences of an ostomy: a study among 1-10-year rectal cancer survivors from the population-based PROFILES registry. Psycho-oncology 23 (9):998-1004. https://doi.org/10.1002/pon.3517

12. Dagan M, Sanderman R, Schokker MC, Wiggers T, Baas PC, van Haastert M, Hagedoorn M (2011) Spousal support and changes in distress over time in couples coping with cancer: the role of personal control. J Fam Psychol 25 (2):310-318. https://doi.org/10.1037/a0022887 13. Hagedoorn M, Dagan M, Puterman E, Hoff C, Meijerink WJ, Delongis A, Sanderman R (2011) Relationship satisfaction in couples confronted with colorectal cancer: the interplay of past and current spousal support. J Behav Med 34 (4):288-297.

https://doi.org/10.1007/s10865-010-9311-7

14. Cornish JA, Tan E, Teare J, Teoh TG, Rai R, Darzi AW, Paraskevas P, Clark SK, Tekkis PP (2007) The effect of restorative proctocolectomy on sexual function, urinary function, fertility, pregnancy and delivery: a systematic review. Dis Colon Rectum 50 (8):1128-1138. https://doi.org/10.1007/s10350-007-0240-7

15. Ho VP, Lee Y, Stein SL, Temple LK (2011) Sexual function after treatment for rectal cancer: a review. Dis Colon Rectum 54 (1):113-125.

https://doi.org/10.1007/DCR.0b013e3181fb7b82 
16. Breukink SO, Donovan KA (2013) Physical and psychological effects of treatment on sexual functioning in colorectal cancer survivors. J Sex Med 10 Suppl 1:74-83. https://doi.org/10.1111/jsm.12037

17. Daniels IR, Woodward S, Taylor FG, Raja A, Toomey P (2006) Female urogenital dysfunction following total mesorectal excision for rectal cancer. World J Surg Oncol 4:6. https://doi.org/10.1186/1477-7819-4-6

18. Lange MM, Marijnen CA, Maas CP, Putter H, Rutten HJ, Stiggelbout AM, MeershoekKlein Kranenbarg E, van de Velde CJ, Cooperative clinical investigators of the D (2009) Risk factors for sexual dysfunction after rectal cancer treatment. Eur J Cancer 45 (9):1578-1588. https://doi.org/10.1016/j.ejca.2008.12.014

19. Frick MA, Vachani CC, Hampshire MK, Bach C, Arnold-Korzeniowski K, Metz JM, Hill-Kayser CE (2017) Survivorship after lower gastrointestinal cancer: Patient-reported outcomes and planning for care. Cancer 123 (10):1860-1868.

https://doi.org/10.1002/cncr.30527

20. Institut National du Cancer (2014) La vie deux ans après un diagnostic de cancer - De l'annonce à l'après cancer. http://www.e-cancer.fr/Expertises-et-publications/Catalogue-despublications/La-vie-deux-ans-apres-un-diagnostic-de-cancer-De-l-annonce-a-1-apres-cancer. 21. Ben Charif A, Bouhnik AD, Courbière B, Rey D, Préau M, Bendiane M-K, Peretti-Watel P, Mancini J (2016) Sexual health problems in French cancer survivors 2 years after diagnosis-the national VICAN survey. J Cancer Surviv 10 (3):600-609. https://doi.org/10.1007/s11764-015-0506-3

22. Bouhnik AD, Bendiane MK, Cortaredona S, Sagaon Teyssier L, Rey D, Berenger C, Seror V, Peretti-Watel P, members of VG (2015) The labour market, psychosocial outcomes and health conditions in cancer survivors: protocol for a nationwide longitudinal survey 2 and 
5 years after cancer diagnosis (the VICAN survey). BMJ Open 5 (3):e005971.

https://doi.org/10.1136/bmjopen-2014-005971

23. Alleaume C, Bendiane MK, Bouhnik AD, Rey D, Cortaredona S, Seror V, Peretti-Watel P (2018) Chronic neuropathic pain negatively associated with employment retention of cancer survivors: evidence from a national French survey. J Cancer Surviv 12 (1):115-126. https://doi.org/10.1007/s11764-017-0650-z

24. Berglund G, Nystedt M, Bolund C, Sjödén PO, Rutquist LE (2001) Effect of endocrine treatment on sexuality in premenopausal breast cancer patients: a prospective randomized study. Journal of clinical oncology : official journal of the American Society of Clinical Oncology 19 (11):2788-2796

25. Tavallaii SA, Fathi-Ashtiani A, Nasiri M, Assari S, Maleki P, Einollahi B (2007) Correlation between sexual function and postrenal transplant quality of life: does gender matter? J Sex Med 4 (6):1610-1618. https://doi.org/10.1111/j.1743-6109.2007.00565.x 26. Assari S, Moghani Lankarani M, Ahmadi K, Kazemi Saleh D (2014) Association between Sexual Function and Marital Relationship in Patients with Ischemic Heart Disease. J Tehran Heart Cent 9 (3):124-131

27. Ben Charif A, Bouhnik AD, Courbiere B, Rey D, Preau M, Bendiane MK, Peretti-Watel P, Mancini J (2016) Sexual health problems in French cancer survivors 2 years after diagnosis-the national VICAN survey. J Cancer Surviv 10 (3):600-609. https://doi.org/10.1007/s11764-015-0506-3

28. Gilbert E, Perz J, Ussher JM (2016) Talking about sex with health professionals: the experience of people with cancer and their partners. Eur J Cancer Care (Engl) 25 (2):280-293. https://doi.org/10.1111/ecc.12216

29. Almont T, Couteau C, Etienne H, Bondil P, Guimbaud R, Schover L, Huyghe E (2018) Sexual health and needs for sexology care in digestive cancer patients undergoing 
chemotherapy: a 4-month cross-sectional study in a French University Hospital. Support Care Cancer. https://doi.org/10.1007/s00520-018-4125-1

30. Kilic E, Taycan O, Belli AK, Ozmen M (2007) [The effect of permanent ostomy on body image, self-esteem, marital adjustment, and sexual functioning]. Turk Psikiyatri Derg 18 (4):302-310

31. Aktas D, Gocman Baykara Z (2015) Body Image Perceptions of Persons With a Stoma and Their Partners: A Descriptive, Cross-sectional Study. Ostomy Wound Manage 61 (5):2640

32. Saito N, Ono M, Sugito M, Ito M, Morihiro M, Kosugi C, Sato K, Kotaka M, Nomura S, Arai M, Kobatake T (2004) Early results of intersphincteric resection for patients with very low rectal cancer: an active approach to avoid a permanent colostomy. Dis Colon Rectum 47 (4):459-466. https://doi.org/10.1007/s10350-003-0088-4

33. Dumont F, Mariani A, Elias D, Goere D (2015) Surgical strategy for low rectal cancers. J Visc Surg 152 (1):23-31. https://doi.org/10.1016/j.jviscsurg.2014.10.005 34. da Silva AL, Hayck J, Deoti B (2014) Perineal colostomy: an alternative to avoid permanent abdominal colostomy: operative technique, results and reflection. Arq Bras Cir Dig 27 (4):243-246. https://doi.org/10.1590/S0102-67202014000400004

35. Almont T, Delannes M, Ducassou A, Corman A, Bondil P, Moyal E, Schover L, Eric H (2017) Sexual quality of life and needs for sexual care of cancer patients admitted for radiotherapy : a 3-month cross-sectional study. J Sex Med 14 (4):566-576. https://doi.org/10.1016/j.jsxm.2017.02.013 36. Ussher JM, Perz J, Gilbert E, Wong WK, Mason C, Hobbs K, Kirsten L (2013) Talking about sex after cancer: a discourse analytic study of health care professional accounts of sexual communication with patients. Psychol Health 28 (12):1370-1390. https://doi.org/10.1080/08870446.2013.811242 
37. Mancini J, Rey D, Preau M, Malavolti L, Moatti JP (2008) Infertility induced by cancer treatment: inappropriate or no information provided to majority of French survivors of cancer. Fertility and sterility 90 (5):1616-1625. https://doi.org/10.1016/j.fertnstert.2007.08.064 38. Hordern A, Street A (2007) Issues of intimacy and sexuality in the face of cancer: the patient perspective. Cancer nursing 30 (6):E11-18. https://doi.org/10.1097/01.NCC.0000300162.13639.f5 39. Eker F, Acikgoz F (2011) The impact of cancer and its treatment on sexual desire, satisfaction and functioning: findings from an exploratory study in rural Turkey. European journal of cancer care 20 (6):769-775. https://doi.org/10.1111/j.1365-2354.2011.01262.x 40. Reese JB, Porter LS, Somers TJ, Keefe FJ (2012) Pilot feasibility study of a telephonebased couples intervention for physical intimacy and sexual concerns in colorectal cancer. $\mathbf{J}$ Sex Marital Ther 38 (5):402-417. https://doi.org/10.1080/0092623X.2011.606886 41. Dyer K, das Nair R (2013) Why don't healthcare professionals talk about sex? A systematic review of recent qualitative studies conducted in the United kingdom. The journal of sexual medicine 10 (11):2658-2670. https://doi.org/10.1111/j.1743-6109.2012.02856.x 42. Julien JO, Thom B, Kline NE (2010) Identification of barriers to sexual health assessment in oncology nursing practice. Oncol Nurs Forum 37 (3):E186-190. https://doi.org/10.1188/10.ONF.E186-E190

43. Park ER, Norris RL, Bober SL (2009) Sexual health communication during cancer care: barriers and recommendations. Cancer J 15 (1):74-77. https://doi.org/10.1097/PPO.0b013e31819587dc 44. Puts MT, Papoutsis A, Springall E, Tourangeau AE (2012) A systematic review of unmet needs of newly diagnosed older cancer patients undergoing active cancer treatment. Support Care Cancer 20 (7):1377-1394. https://doi.org/10.1007/s00520-012-1450-7 
45. Milbury K, Cohen L, Jenkins R, Skibber JM, Schover LR (2013) The association between psychosocial and medical factors with long-term sexual dysfunction after treatment for colorectal cancer. Supportive care in cancer : official journal of the Multinational Association of Supportive Care in Cancer 21 (3):793-802. https://doi.org/10.1007/s00520-012-1582-9 46. Hall AE, Boyes AW, Bowman J, Walsh RA, James EL, Girgis A (2012) Young adult cancer survivors' psychosocial well-being: a cross-sectional study assessing quality of life, unmet needs, and health behaviors. Supportive care in cancer : official journal of the Multinational Association of Supportive Care in Cancer 20 (6):1333-1341. https://doi.org/10.1007/s00520-011-1221-x

47. Li WWY, Lam WWT, Au AHY, Ye M, Law WL, Poon J, Kwong A, Suen D, Tsang J, Girgis A, Fielding R (2013) Interpreting differences in patterns of supportive care needs between patients with breast cancer and patients with colorectal cancer. Psycho-oncology 22 (4):792-798. https://doi.org/10.1002/pon.3068

48. McCallum M, Lefebvre M, Jolicoeur L, Maheu C, Lebel S (2012) Sexual health and gynecological cancer: conceptualizing patient needs and overcoming barriers to seeking and accessing services. Journal of psychosomatic obstetrics and gynaecology 33 (3):135-142. https://doi.org/10.3109/0167482X.2012.709291

49. Reese JB, Shelby RA, Abernethy AP (2011) Sexual concerns in lung cancer patients: an examination of predictors and moderating effects of age and gender. Support Care Cancer 19 (1):161-165. https://doi.org/10.1007/s00520-010-1000-0

50. Almont T, Farsi F, Krakowski I, El Osta R, Bondil P, Huyghe E (2018) Sexual health in cancer: the results of a survey exploring practices, attitudes, knowledge, communication, and professional interactions in oncology healthcare providers. Support Care Cancer. https://doi.org/10.1007/s00520-018-4376-x 
51. Huyghe E, Almont T, Burte C, Marx E, Habold D, BONDIL P (2016) [Training in oncosexology: current and future provisions]. Psycho-Oncologie 10 (2):85-90.

https://doi.org/10.1007/s11839-016-0568-4 



\section{TABLES}

\section{Table 1: Patients' characteristics}

\begin{tabular}{|c|c|c|c|c|c|c|}
\hline & \multicolumn{3}{|c|}{ By gender } & \multicolumn{3}{|c|}{ By cancer site } \\
\hline & Men & Women & $p$ & Colon & Rectum & $p$ \\
\hline & mean $\pm s d$ & mean $\pm s d$ & & mean $\pm s d$ & mean $\pm s d$ & \\
\hline \multirow{2}{*}{ Age at diagnosis } & $57 \pm 13$ & $55 \pm 13$ & $.032 *$ & $56 \pm 13$ & $55 \pm 14$ & .198 \\
\hline & N/Total (\%) & N/Total (\%) & & N/Total (\%) & N/Total (\%) & \\
\hline Age $>55$ at diagnosis & 109/258 (42) & $73 / 229(32)$ & $.018^{*}$ & $145 / 374(39)$ & $37 / 113(33)$ & .246 \\
\hline Having a partner at time of survey & $204 / 258$ (79) & $161 / 229(70)$ & $.026^{*}$ & $277 / 374(74)$ & $88 / 113(78)$ & .412 \\
\hline $\begin{array}{l}\text { Having at least } 1 \text { dependent child at home at time of } \\
\text { survey }\end{array}$ & $74 / 258(29)$ & $76 / 229(33)$ & .282 & $110 / 374(29)$ & $40 / 113(35)$ & .227 \\
\hline Live in a (peri)urban environment (vs. Rural) & $173 / 257(67)$ & $164 / 228(72)$ & .271 & 259/372 (70) & $78 / 113(69)$ & .904 \\
\hline Education < Bachelor Degree & $155 / 257(60)$ & $126 / 229(55)$ & .239 & $216 / 373(58)$ & $65 / 113(58)$ & .942 \\
\hline Having a job at diagnosis (vs. unemployed/retired) & $113 / 252(45)$ & $103 / 225(46)$ & .837 & 195/366 (53) & $66 / 111(59)$ & .252 \\
\hline Household income $\leq 1,500 € /$ month at time of survey & $125 / 241(52)$ & $116 / 210(55)$ & .474 & $186 / 342(54)$ & $55 / 109(50)$ & .474 \\
\hline Colon cancer (vs. Rectum) & 184/258 (71) & 190/229 (83) & .002 ** & - & - & - \\
\hline Treatment including chemotherapy & $161 / 258(62)$ & $152 / 229(66)$ & .361 & $224 / 374(60)$ & $89 / 113(79)$ & $<.001^{* * *}$ \\
\hline Treatment including radiotherapy & $82 / 258(32)$ & $35 / 229(15)$ & $<.001 * * *$ & $41 / 374(11)$ & $76 / 113(67)$ & $<.001 * * *$ \\
\hline Treatment including surgery & $139 / 258(54)$ & $108 / 229(47)$ & .139 & $142 / 374(35)$ & $105 / 113(93)$ & $<.001^{* * *}$ \\
\hline Treatment including ostomy & $63 / 258(24)$ & $36 / 229(16)$ & $.017^{*}$ & $45 / 374(12)$ & $54 / 113(48)$ & $<.001^{* * *}$ \\
\hline Fecal incontinence during the past 7 days & $51 / 258(20)$ & $49 / 229(21)$ & .657 & $64 / 374(17)$ & $36 / 113(32)$ & $.001 * * *$ \\
\hline Diabetic & $22 / 258(9)$ & $8 / 229(3)$ & $.021 *$ & $25 / 374(7)$ & $5 / 113(4)$ & .381 \\
\hline
\end{tabular}


Table 2: Factors associated with decrease in sexual desire

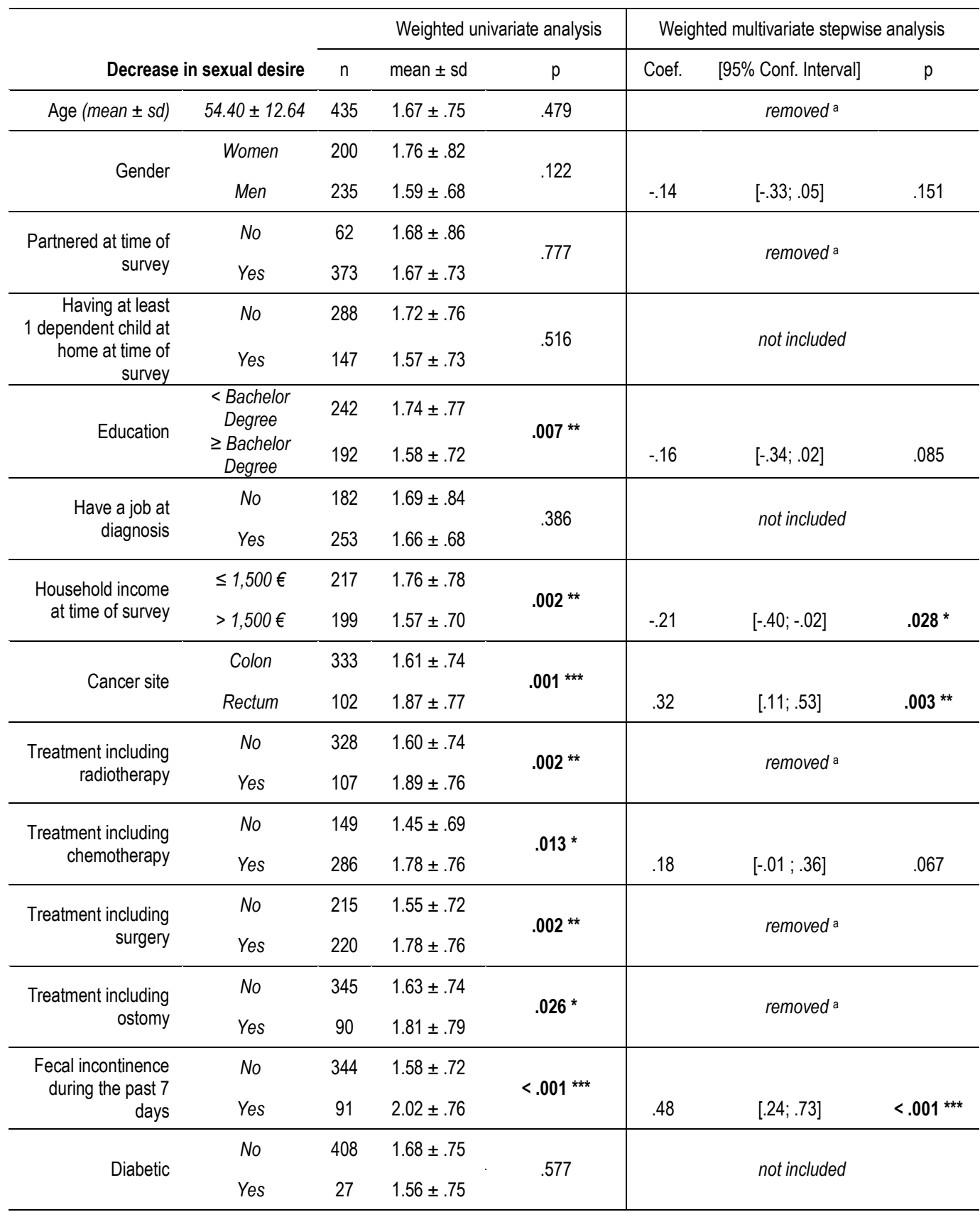

7 a removed because $p>20$ in multivariate model

$8 \quad{ }^{*} p \leq .05 ;{ }^{* *} p \leq .01 ;{ }^{* * *} p \leq .001$ 
Table 3: Factors associated with decrease in the frequency of intercourse

\begin{tabular}{|c|c|c|c|c|c|c|c|}
\hline \multirow{2}{*}{\multicolumn{2}{|c|}{ Decrease in the frequency of intercourse }} & \multicolumn{3}{|c|}{ Weighted univariate analysis } & \multicolumn{3}{|c|}{ Weighted multivariate stepwise analysis } \\
\hline & & $\mathrm{n}$ & mean $\pm \mathrm{sd}$ & $p$ & Coef. & [95\% Conf. Interval] & $p$ \\
\hline \multirow[t]{2}{*}{ Age (mean $\pm s d)$} & $53.93 \pm 12.44$ & 402 & $2.95 \pm .94$ & .329 & .01 & {$[-.00 ; .02]$} & .173 \\
\hline & $\begin{array}{c}\text { Women } \\
\text { Men }\end{array}$ & $\begin{array}{l}179 \\
223\end{array}$ & $\begin{array}{l}2.96 \pm .96 \\
2.95 \pm .92\end{array}$ & .767 & \multicolumn{3}{|c|}{ removed a } \\
\hline $\begin{array}{r}\text { Partnered at time of } \\
\text { survey }\end{array}$ & $\begin{array}{l}\text { No } \\
\text { Yes }\end{array}$ & $\begin{array}{l}42 \\
360\end{array}$ & $\begin{array}{l}2.93 \pm 1.07 \\
2.95 \pm .93\end{array}$ & .439 & \multicolumn{3}{|c|}{ removed a } \\
\hline $\begin{array}{r}\text { Having at least } \\
1 \text { dependent child at } \\
\text { home at time of } \\
\text { survey }\end{array}$ & $\begin{array}{l}\text { No } \\
\text { Yes }\end{array}$ & $\begin{array}{l}258 \\
144\end{array}$ & $\begin{array}{l}2.91 \pm .95 \\
3.02 \pm .92 \\
\end{array}$ & $.046 *$ & \multicolumn{3}{|c|}{ removed a } \\
\hline Education & $\begin{array}{l}<\text { Bachelor Degree } \\
\geq \text { Bachelor Degree }\end{array}$ & $\begin{array}{l}221 \\
180\end{array}$ & $\begin{array}{l}3.00 \pm .94 \\
2.89 \pm .94\end{array}$ & .199 & \multicolumn{3}{|c|}{ removed a } \\
\hline $\begin{array}{r}\text { Have a job at } \\
\text { diagnosis }\end{array}$ & $\begin{array}{l}\text { No } \\
\text { Yes }\end{array}$ & $\begin{array}{l}160 \\
242\end{array}$ & $\begin{array}{l}2.84 \pm .98 \\
3.02 \pm .91\end{array}$ & $.007^{* *}$ & .33 & {$[.05 ; .62]$} & $.022 *$ \\
\hline $\begin{array}{l}\text { Household income } \\
\text { at time of survey }\end{array}$ & $\begin{array}{l}\leq 1,500 € \\
>1,500 €\end{array}$ & $\begin{array}{l}197 \\
189\end{array}$ & $\begin{array}{l}3.06 \pm .97 \\
2.84 \pm .91\end{array}$ & $.041^{*}$ & -.32 & {$[-.54 ;-.10]$} & $.005^{* *}$ \\
\hline Cancer site & $\begin{array}{l}\text { Colon } \\
\text { Rectum }\end{array}$ & $\begin{array}{l}305 \\
97\end{array}$ & $\begin{array}{l}2.85 \pm .94 \\
3.26 \pm .89\end{array}$ & $.001 * * *$ & \multicolumn{3}{|c|}{ removed a } \\
\hline $\begin{array}{l}\text { Treatment including } \\
\text { radiotherapy }\end{array}$ & $\begin{array}{l}\text { No } \\
\text { Yes }\end{array}$ & $\begin{array}{l}300 \\
102\end{array}$ & $\begin{array}{l}2.81 \pm .93 \\
3.35 \pm .86\end{array}$ & $.001^{* * *}$ & \multicolumn{3}{|c|}{ removed a } \\
\hline $\begin{array}{r}\text { Treatment including } \\
\text { chemotherapy }\end{array}$ & $\begin{array}{l}\text { No } \\
\text { Yes }\end{array}$ & $\begin{array}{l}138 \\
264\end{array}$ & $\begin{array}{l}2.65 \pm .86 \\
3.11 \pm .95\end{array}$ & $.002 * *$ & .25 & {$[.01 ; .49]$} & $.040 *$ \\
\hline $\begin{array}{r}\text { Treatment including } \\
\text { surgery }\end{array}$ & $\begin{array}{l}\text { No } \\
\text { Yes }\end{array}$ & $\begin{array}{l}199 \\
203\end{array}$ & $\begin{array}{l}2.72 \pm .93 \\
3.17 \pm .90\end{array}$ & $<.001 * * *$ & .39 & {$[.15 ; .63]$} & $.001^{* *}$ \\
\hline $\begin{array}{r}\text { Treatment including } \\
\text { ostomy }\end{array}$ & $\begin{array}{l}\text { No } \\
\text { Yes }\end{array}$ & $\begin{array}{l}320 \\
82\end{array}$ & $\begin{array}{l}2.88 \pm .94 \\
3.24 \pm .88\end{array}$ & $.002 * *$ & \multicolumn{3}{|c|}{ removed a } \\
\hline $\begin{array}{r}\text { Fecal incontinence } \\
\text { during the past } 7 \\
\text { days }\end{array}$ & $\begin{array}{l}\text { No } \\
\text { Yes }\end{array}$ & $\begin{array}{l}319 \\
83\end{array}$ & $\begin{array}{l}2.85 \pm .92 \\
3.35 \pm .90\end{array}$ & $<.001 * * *$ & .46 & {$[.19 ; .73]$} & $.001 * * *$ \\
\hline Diabetic & $\begin{array}{l}\text { No } \\
\text { Yes }\end{array}$ & $\begin{array}{l}378 \\
24\end{array}$ & $\begin{array}{l}2.98 \pm .94 \\
2.50 \pm .78\end{array}$ & $.029 *$ & -.38 & {$[-.80 ; .03]$} & .072 \\
\hline
\end{tabular}

12
13

a removed because $p>20$ in multivariate model

${ }^{*} p \leq .05 ;{ }^{* *} p \leq .01 ;{ }^{* *} p \leq .001$ 
Table 4: Factors associated with difficulty to reach an orgasm

16

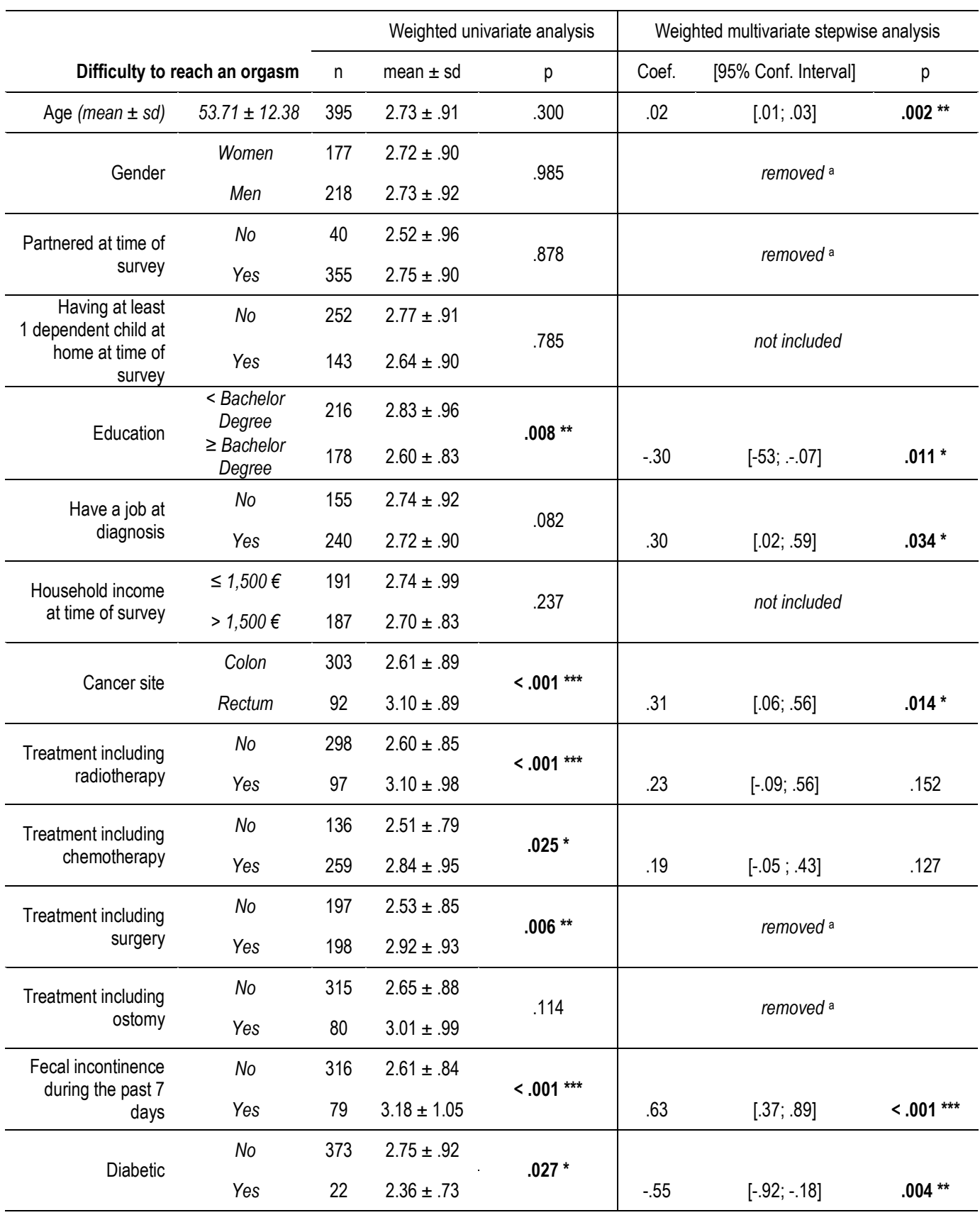

17 a removed because $p>20$ in multivariate model

18 * $p \leq .05 ;{ }^{* *} p \leq .01 ;{ }^{* * *} p \leq .001$ 
Table 5: Factors associated with satisfaction with frequency of hugging and kissing

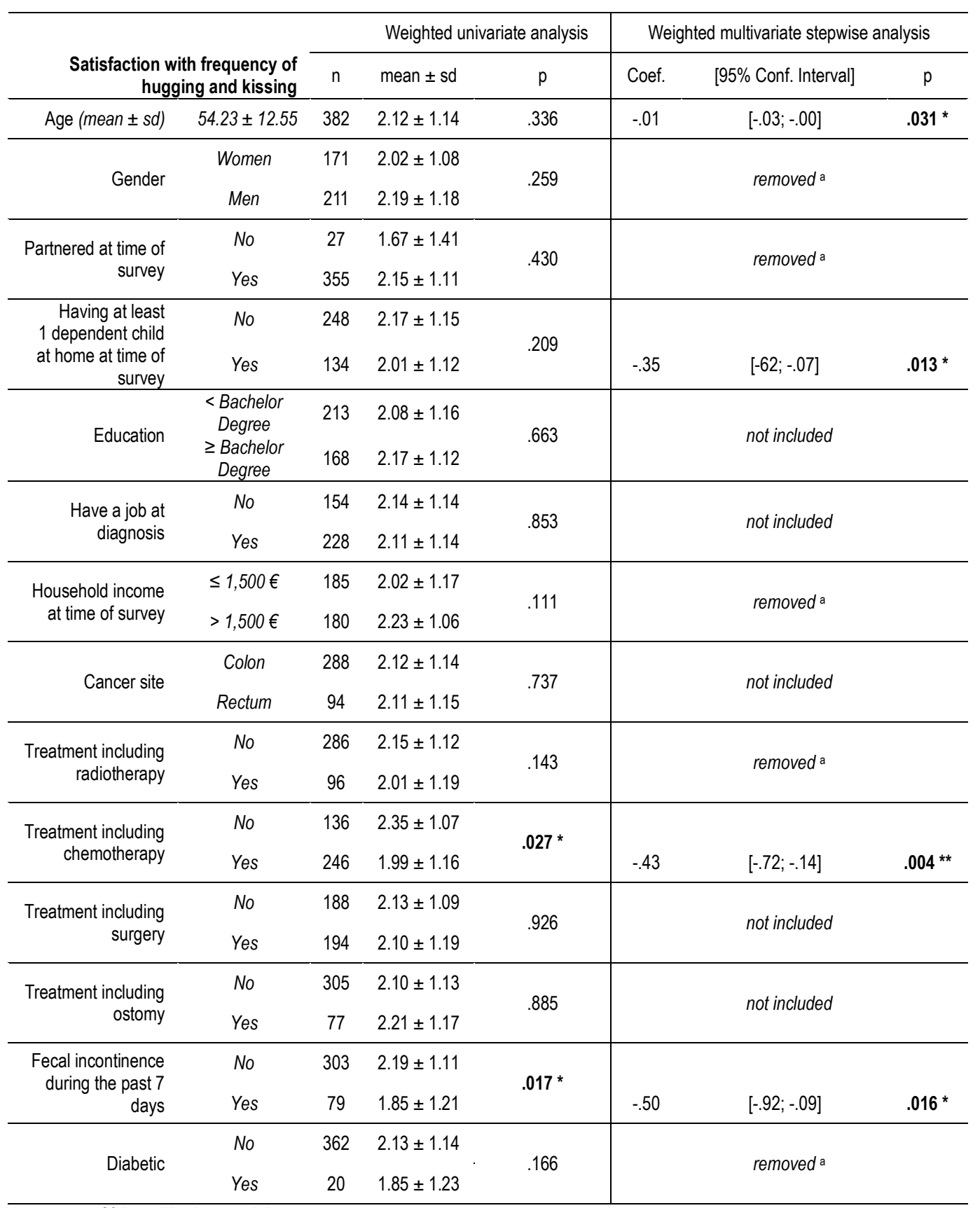

23 a removed because $p>20$ in multivariate model

$24 \quad{ }^{*} p \leq .05 ;{ }^{* *} p \leq .01 ;{ }^{* * *} p \leq .001$ 
Table 6: Factors associated with satisfaction with frequency of intercourse

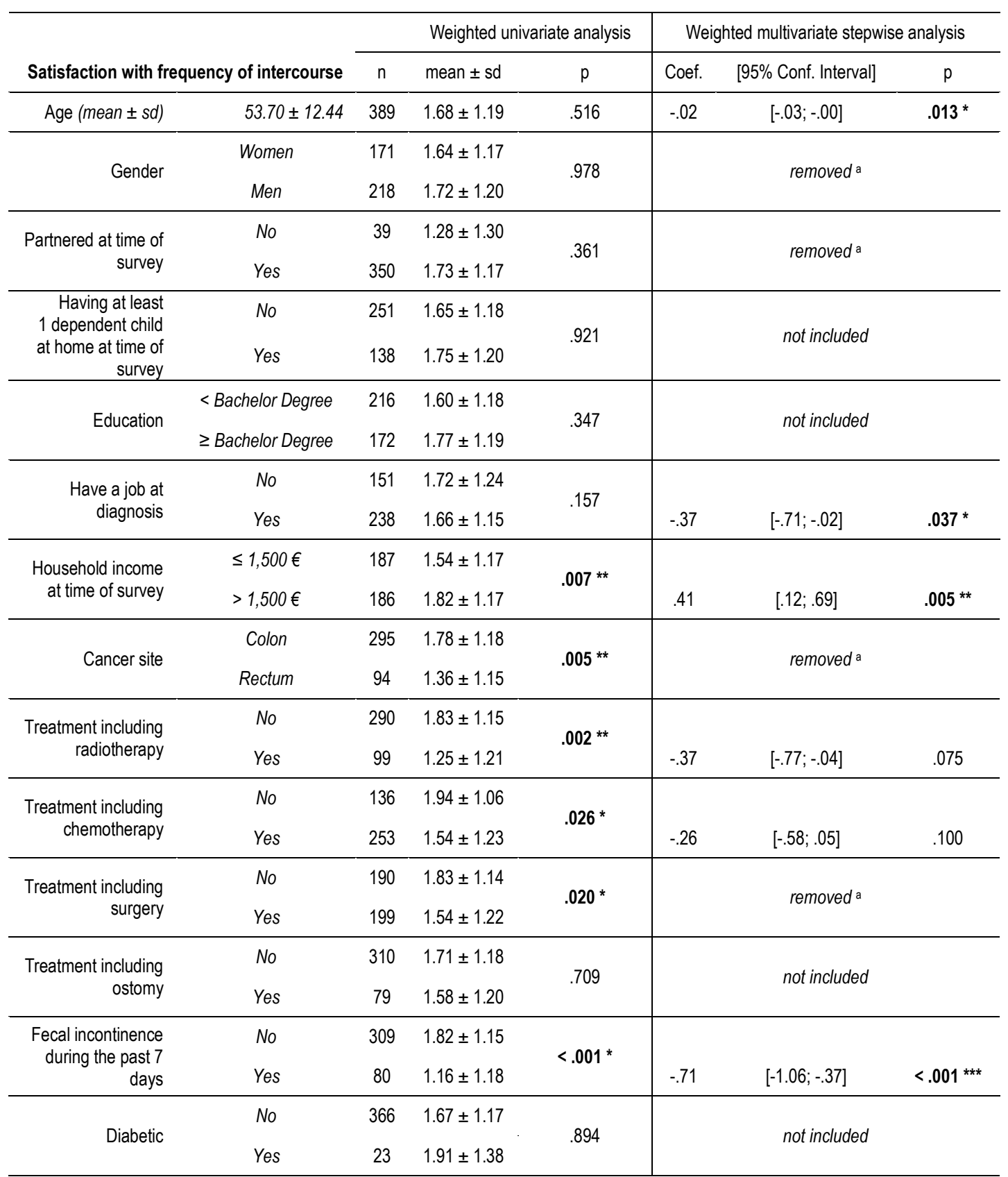

28 a removed because $p>20$ in multivariate model

$29 \quad * p \leq .05 ;{ }^{* *} p \leq .01 ;{ }^{* * *} p \leq .001$ 
Table 7: Factors associated with the frequency (no.) of intercourses during the last two weeks

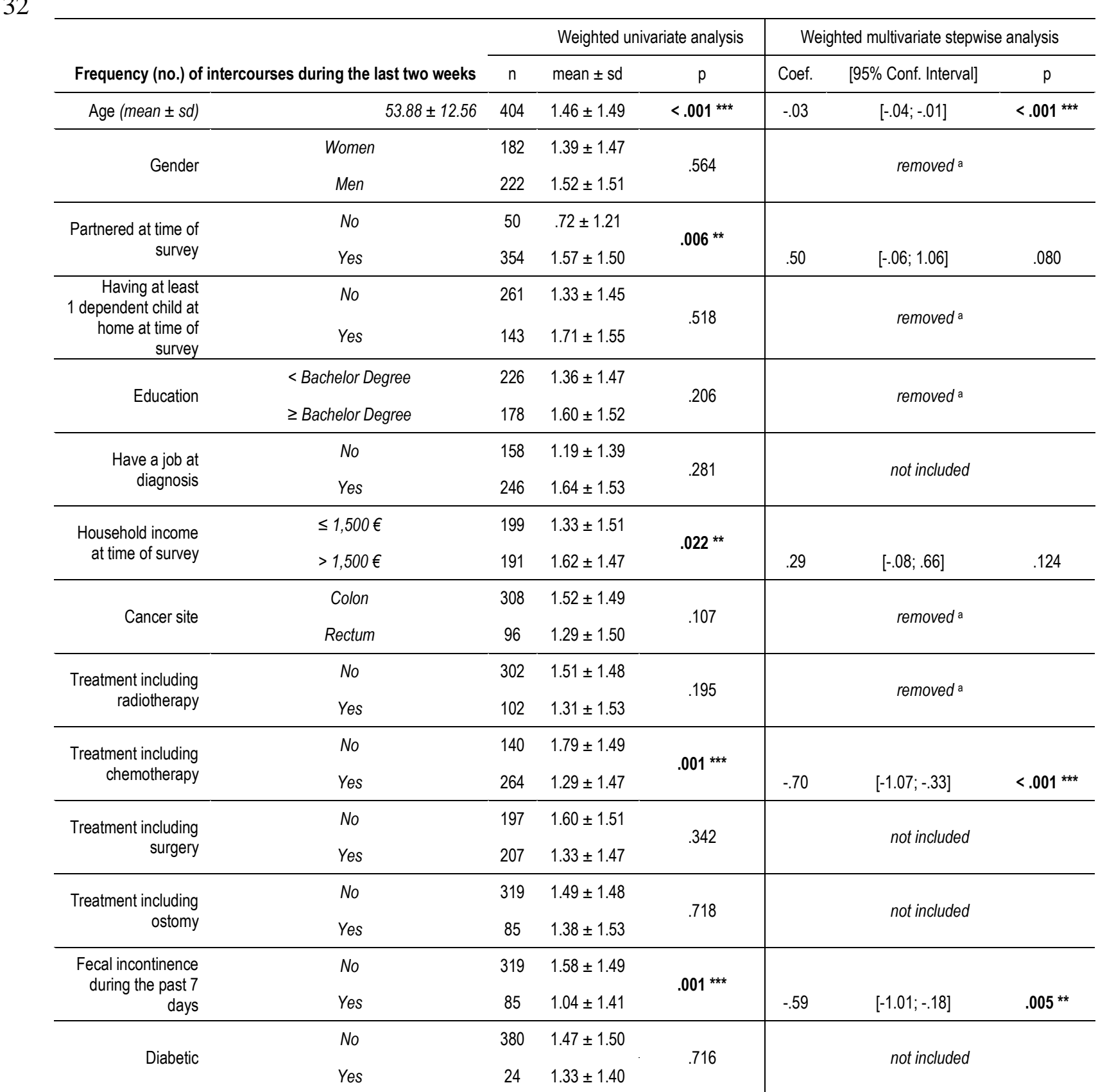

33 a removed because $p>20$ in multivariate model

$34 \quad{ }^{*} p \leq .05 ;{ }^{* *} p \leq .01 ;{ }^{* *} p \leq .001$ 
Table 8: Factors associated with discussing sexuality with the medical team

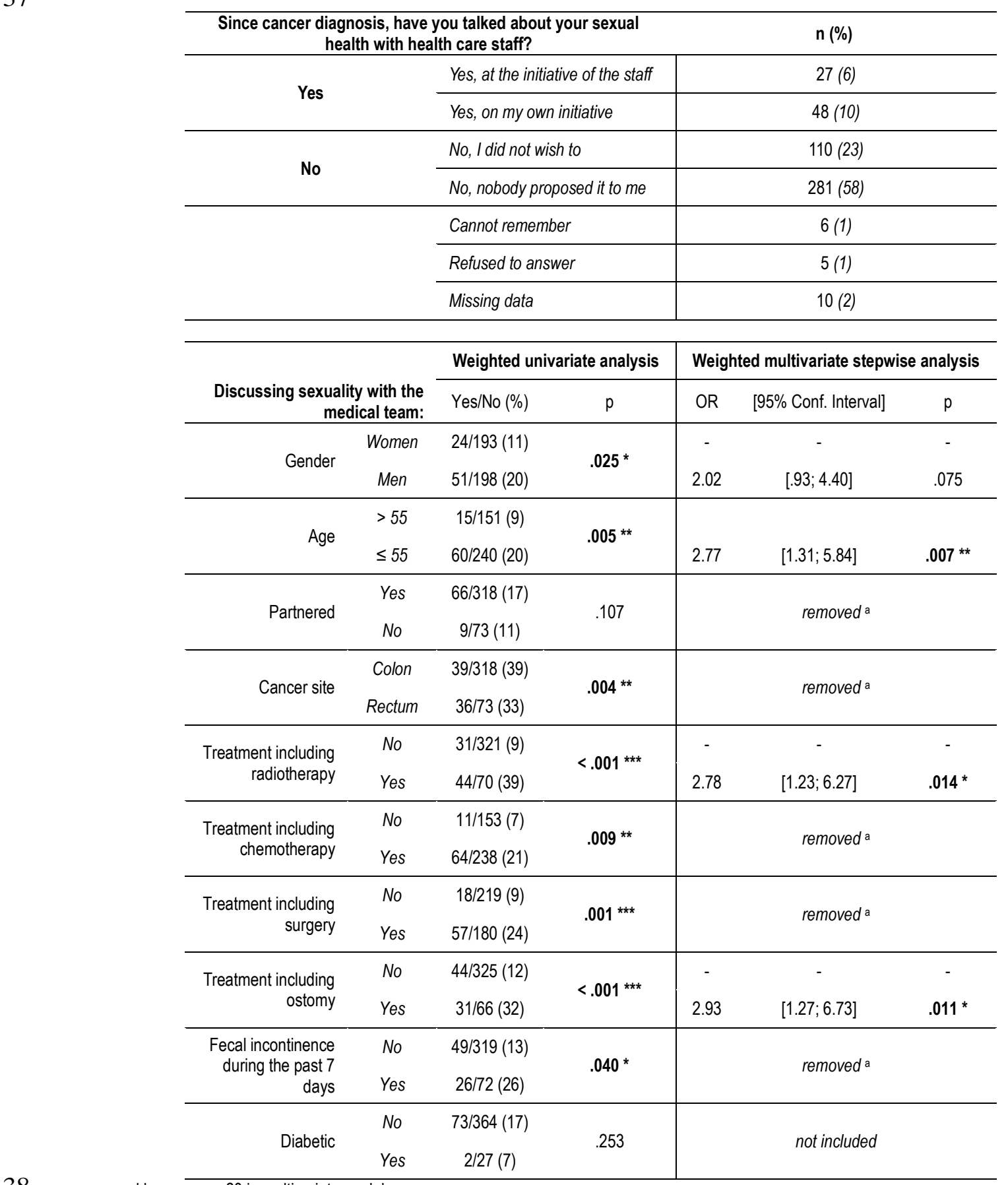

38 a removed because $p>20$ in multivariate model

$39{ }^{*} p \leq .05 ;{ }^{* *} p \leq .01 ;{ }^{* * *} p \leq .001$ 